\title{
UNUSUAL CLINICAL COURSE OF NEUROSARCOIDOSIS MANIFESTED WITH ACUTE HYDROCEPHALUS
}

\author{
Dragana Jovanović ${ }^{1,2}$, Dana Grujičić ${ }^{1,3}$, Mihailo Stjepanović ${ }^{1,2}$, Spasoje Popević ${ }^{1,2}$, \\ Milica Kontić, ${ }^{1,2}$ and Violeta Vučinić Mihailović ${ }^{1,3}$ \\ ${ }^{1}$ Medical Faculty, University of Belgrade, Belgrade, Serbia; \\ ${ }^{2}$ Department of Pulmonology, Clinical Center of Serbia, Belgrade, Serbia; \\ ${ }^{3}$ Department of Neurosurgery, Clinical Center of Serbia, Belgrade, Serbia
}

\begin{abstract}
SUMMARY - Approximately $5 \%$ to $15 \%$ of patients with systemic sarcoidosis develop neurological complications. However, the actual prevalence of subclinical disease may be higher. Symptoms are not specific, and may resemble those of other neurological diseases. Hydrocephalus occurs in $6 \%$ of patients with neurosarcoidosis. Acute hydrocephalus is extremely rare and when it occurs, it is usually difficult to diagnose, thus leading to possible complications. We present a patient who developed acute hydrocephalus due to neurosarcoidosis, for which he had to be operated on; soon after the operation, cranial infection developed that required definitive drainage system and ventriculoperitoneal shunt had to be implanted. In further complicated clinical course, after four years on corticosteroid therapy (corticosteroid dependent sarcoidosis), he had to be urgently operated on because of significant ventricular catheter adhesions, but several days after the operation he died in coma because of progressive brain edema not responding to treatment. As hydrocephalus due to neurosarcoidosis has high morbidity and mortality, early diagnosis and proper treatment are of utmost importance.
\end{abstract}

Key words: Sarcoidosis; Neurosarcoidosis; Hydrocephalus; Treatment

\section{Introduction}

Sarcoidosis is a granulomatous multisystem multiorgan disorder of unknown etiology and unpredictable course $^{1}$. Approximately $5 \%$ to $15 \%$ of patients with systemic sarcoidosis develop neurological complications. However, the actual prevalence of subclinical disease may be higher. Postmortem studies suggest that only half of neurosarcoidosis cases are diagnosed during lifetime, before autopsy ${ }^{2,3}$. Symptoms are not specific, and may resemble those of other neurological diseases ${ }^{4,5}$. Hydrocephalus occurs in $6 \%$ of patients with neurosarcoidosis. Acute hydrocephalus is extremely rare and when it occurs, it is usually difficult to diagnose, thus leading to possible complications ${ }^{6}$.

Correspondence to: Mihailo Stjepanovic, $M D, P h D$, Department of Pulmonology, Clinical Center of Serbia, Koste Todorovića 26/20, 11000 Belgrade, Serbia

E-mail: mihailostjepanovic@gmail.com

Received May 10, 2017, accepted March 7, 2018
We present a patient who developed acute hydrocephalus due to neurosarcoidosis, for which he had to be operated on; however, soon after the operation, he developed cranial infection that required definitive drainage system and ventriculoperitoneal shunt had to be implanted. In further complicated clinical course, after four years on corticosteroid therapy (corticosteroid dependent sarcoidosis), he had to be urgently operated on because of significant ventricular catheter adhesions, but several days after the operation he died in coma because of progressive brain edema not responding to treatment.

\section{Case Report}

A 27-year-old male patient suffered from asthma from his early childhood. In the autumn 1998, profound headaches and skin lesions developed, the latter proven by biopsy to be skin sarcoidosis. Due to asthma 


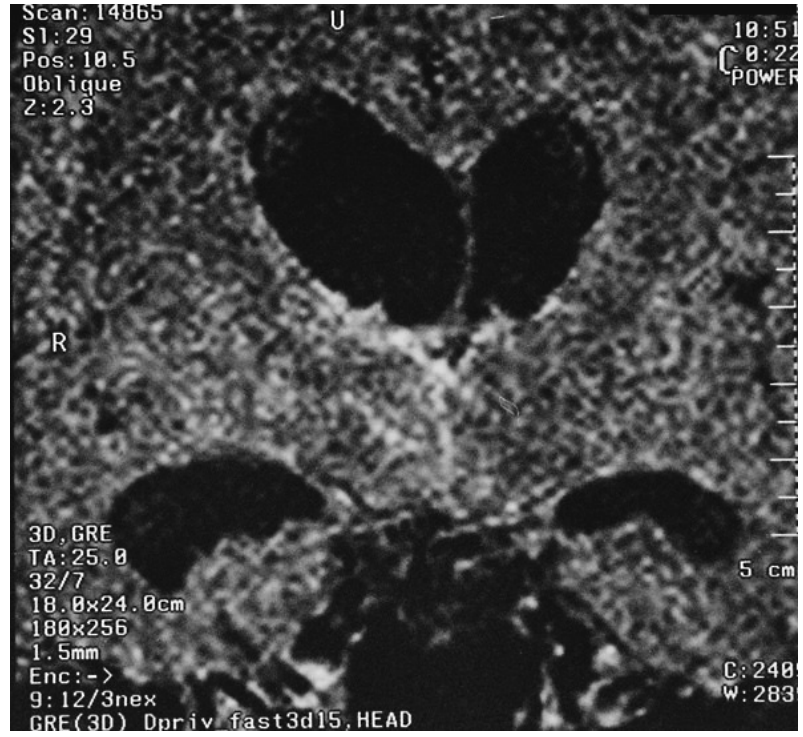

Fig. 1. Magnetic resonance image of the central nervous system: granulomatous changes in the right foramen of Monro and third ventricle.

deterioration in February 1999, he was examined by a pulmonologist, and chest $\mathrm{x}$-ray revealed bilateral hilar lymphadenopathy (BHLA) and parenchymal lesions.

He was admitted to the hospital due to unbearable headache and dizziness. Urgent computed tomography (CT) scan of the brain showed enlargement of the right lateral ventricle and prominent brain edema, while magnetic resonance imaging (MRI) revealed granulomatous lesions in the right foramen of Monro and third brain ventricle entry, i.e., acute hydrocephalus (Fig. 1).

After three weeks of intensive steroid therapy, with regression of symptoms, clinical and CT improvement, he was dismissed from the hospital with maintenance doses of steroid therapy. A month later, acute unilateral hydrocephalus developed again (Fig. 2), with no further response to intensified steroid therapy, and the patient had to be operated on as emergency. Perioperative finding was complete obstruction of the right foramen of Monro and third brain ventricle entry with granuloma. Histologic analysis showed noncaseating sarcoid granulomas.

Definitive drainage system, i.e., ventriculoperitoneal shunt, was implanted. He was prescribed prednisolone for the next months. In the autumn 1999, CT scan of the chest showed progression of pulmonary sarcoidosis (Fig. 3). A year later, the patient developed

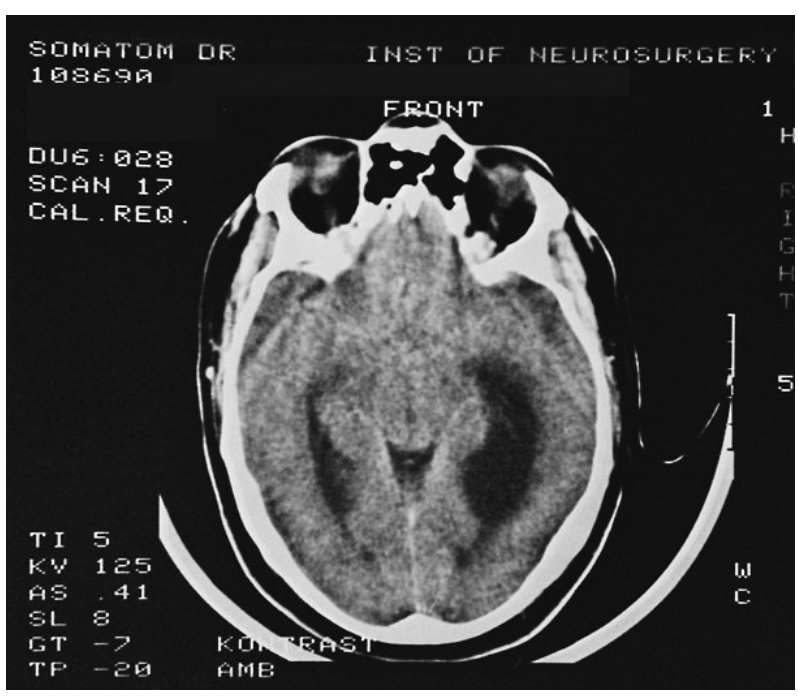

Fig. 2. Acute unilateral hydrocephalus with enlargement of the right lateral ventricles and large periventricular dilatation.

left-sided hemiparesis accompanied with polyneuropathy. Brain CT scan showed multiple new sarcoid granulomas. At the same time, secondary hypothyroidism with sleepiness and myxedema was evident and soon after proven (T3 0.77, T4 46.0, Na 133, TSH n.v.), so Tivoral ${ }^{\Phi}$ (Galenika, Serbia) was introduced in therapy.

In March 2000, he was admitted to the hospital in poor performance status, with the signs of profound disseminated sarcoidosis, extreme Cushing syndrome, not able to walk. Brain CT scan showed rapid progression of the lesions, i.e., uncontrollable neurosarcoidosis. The patient and his family refused introduction of a cytostatic drug in therapy, so high doses of prednisone (Pronison ${ }^{\oplus}$, Galenika, Serbia) were administered (80/60 $\mathrm{mg}$ alternatively), which resulted in excellent improvement of clinical and neurological findings. Several weeks later, ketoacidosis developed as one of the manifestations of steroid-induced diabetes (glycemia $47 \mathrm{mmol} / \mathrm{L}$ ). With temporary introduction of insulin and exclusion of Pronison ${ }^{\oplus}$ therapy, glycemia reached normal values that were maintained after stopping insulin therapy. Then, Pronison ${ }^{\oplus}$ was carefully reintroduced at lower doses $(30 / 20 \mathrm{mg}$ alternatively), with really satisfactory resolution of neurosarcoidosis lesions. The patient was stable for the next four years, with no disease manifestation, all the time on maintenance Pronison ${ }^{\oplus}$ therapy (15/10 mg alternatively). 


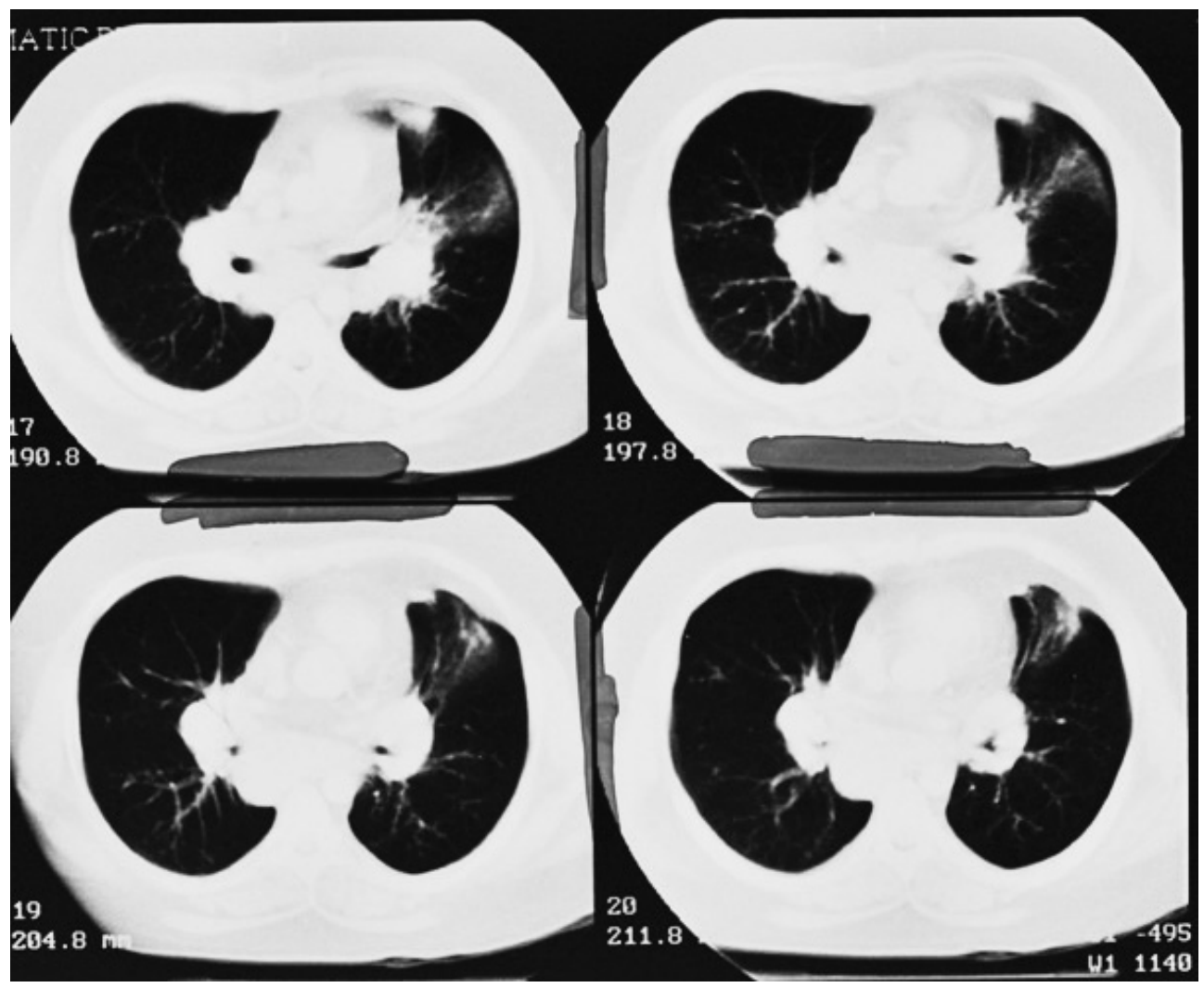

Fig. 3. Bilateral hilar lymphadenopathy and retrocarineal lymph nodes of $54 \mathrm{~mm}$ in diameter; changes basally left and pericardial adhesions.

In April 2004, emergency revision was indicated because of sudden development of the psychoorganic syndrome, disability to control the sphincters, and paraparesis of the legs. CT scan of the central nervous system showed dilatation of the ventricular system. The patient was operated on because of ventricular catheter adhesions in the left ventricle wall. In May 2004, pronounced cognitive changes with ataxia and CT evident cerebrospinal fluid accumulation in the right brain ventricle and parietal region occurred, so he was reoperated on because of the repeat system disconnection. A few days after the operation, the patient died in coma due to progressive brain edema not responding to treatment.

\section{Discussion}

Sarcoidosis can affect any part of the nervous system. Clinical and pathologic changes can result from granulomatous affection of the cranial nerves to increase intracranial pressure ${ }^{7,8}$. Hydrocephalus is a very uncommon finding. To date, there have been five reported cases of hydrocephalus occurring as the first presentation of neurosarcoidosis ${ }^{9,10}$.

In our case, sarcoidosis presented with skin lesions and headache as evident manifestations of neurosarcoidosis. Development of life-threatening hydrocephalus pointed to further progression of neurosarcoidosis, with granulomatous lesions in the right foramen of Monro and third brain ventricle entry, enlargement of the right lateral ventricle and prominent brain ede$\mathrm{ma}^{11,12}$. Although the prognosis of neurosarcoidosis is good, particularly when facial nerve is involved, hydrocephalus is associated with a high mortality rate of $75 \%{ }^{12,13}$. Benzagmout et al. report that after treatment with ventricular shunt and corticosteroid therapy, acute hydrocephalus associated with neurosarcoidosis was resolved ${ }^{14,15}$.

Currently, pharmacological regimens for the treatment of neurosarcoidosis are not standardized since no prospective, randomized, controlled trials have been performed. While a number of medications showed to 
be beneficial for neurosarcoidosis, corticosteroids remain the drugs of choice. If treatment with corticosteroids fails or needs to be discontinued due to adverse reactions, there are other pharmacotherapeutic options such as methotrexate, mycophenolate mofetil, cyclophosphamide, azathioprine, chloroquine and hydroxychloroquine, thalidomide, and infliximab. Of note is the possible exception of infliximab, as the response to alternative medications is relatively slow compared with corticosteroids; therefore, corticosteroids should almost always be administered in case of acute, lifethreatening neurosarcoidosis ${ }^{16}$.

From the therapeutic standpoint, neurosurgery is only indicated when medications fail or when lifethreatening emergencies arise. Complications such as severe hydrocephalus and elevated intracranial pressure can be treated with ventriculoperitoneal shunting.

As hydrocephalus due to neurosarcoidosis has high morbidity and mortality, early diagnosis and proper treatment are of utmost importance.

\section{Acknowledgment}

This work was supported by the Serbian Ministry of Education and Science (grant No. 175046).

\section{References}

1. Statement on sarcoidosis. Joint Statement of the American Thoracic Society (ATS), the European Respiratory Society (ERS) and the World Association of Sarcoidosis and Other Granulomatous Disorders (WASOG) adopted by the ATS Board of Directors and by the ERS Executive Committee, February 1999. Am J Respir Crit Care Med. 1999 Aug; 160(2):736-55. doi: 10.1164/ajrccm.160.2.ats4-99

2. Jovanović D, Vučinić V, Stević R, Milenkovic MR, Samardžić N, Velinović M, et al. Sarcoidosis of the pleura - a case report. Vojnosanit Pregl. 2014;71(5):506-9. doi: 10.2298/VSP1405506J

3. Iwai K, Tachibana T, Takemura T, Matsui Y, Kitaichi M, Kawabata Y. Pathological studies on sarcoidosis autopsy. I. Epidemiological features of 320 cases in Japan. Acta Pathol Jpn. 1993;43 (7-8):372-6. doi: 10.1111/j.1440-1827.1993.tb01148.x.

4. Terushkin V, Stern BJ, Judson MA, Hagiwara M, Pramanik B, Sanchez M, et al. Neurosarcoidosis: presentations and mana- gement. Neurologist. 2010;16(1):2-15. doi: 10.1097/NRL.0b0 $13 \mathrm{e} 3181 \mathrm{c} 92 \mathrm{a} 72$

5. Stjepanović MI, Vučinić VM, Jovanović D, Mijajlović M, Trifunović VS, Stjepanović MM. Diagnosis of neurosarcoidosis - necessity of biopsy. Med Pregl. 2014;67(3-4):97-9. doi: 10.2298/MPNS1404097S

6. Allen RK, Sellars RE, Sandstrom PA. A prospective study of 32 patients with neurosarcoidosis. Sarcoidosis Vasc Diffuse Lung Dis. 2003;20(2):118-25.

7. Nowak DA, Widenka DC. Neurosarcoidosis: a review of its intracranial manifestation. J Neurol. 2001;248:363-72. doi: 10.1007/s004150170175

8. Mijajlovic M, Mirkovic M, Mihailovic-Vucinic V, Aleksic V, Covickovic-Sternic N. Neurosarcoidosis: two case reports with multiple cranial nerve involvement and review of the literature. Biomed Pap Med Fac Univ Palacky Olomouc Czech Repub. 2014 Dec;158(4):662-7. doi: 10.5507/bp.2013.047

9. Lee CH, Jung YS, Lee SH. Hydrocephalus as a presenting manifestation of neurosarcoidosis: easy to misdiagnose as tuberculosis. J Korean Neurosurg Soc. 2010;48:79-81. doi: 10.3340/jkns.2010.48.1.79

10. Lukin RR, Chambers AA, Soleimanpour M. Outlet obstruction of the fourth ventricle in sarcoidosis. Neuroradiology. 1975 Nov 21;10(2):65-8.

11. Hwang JK, Cho JH, Park SY, Son JI, Jo U, Chin SO, et al. A case of possible neurosarcoidosis presenting as intractable headache and panhypopituitarism. Case Rep Endocrinol.2013; 2013:816236. doi: 10.1155/2013/816236

12. Zajicek JP, Scolding NJ, Foster O, Rovaris M, Evanson J, Moseley IF, et al. Central nervous system sarcoidosis - diagnosis and management. QJM. 1999;92:103-17. doi: 10.1093/ qjimed/92.2.103.

13. Stjepanović MI, Vucinić VM, Jovanović D, Mijajlović M, Trifunović VS, Ivanov JV. Radiological presentation of neurosarcoidosis. Med Pregl. 2014 Jan-Feb;67(1-2):24-7. doi: 10.2298/MPNS1402024S

14. Benzagmout M, Boujraf S, Góngora-Rivera F, Bresson D, VanEffenterre R. Neurosarcoidosis which manifested as acute hydrocephalus: diagnosis and treatment. Intern Med. 2007; 46(18):1601-4. doi: 10.2169/internalmedicine.46.0126

15. Novaković N, Lepić M, Minić L, Radenović K, Rotim A, Rasulić L. Combined treatment of ruptured middle cerebral artery aneurysm followed by subarachnoid hemorrhage and acute subdural hematoma in multiple aneurysm disease of cerebral blood vessels: case report. Acta Clin Croat. 2016 Dec; 55(4):659-62. doi: 10.20471/acc.2016.55.04.19

16. Patel AV, Stickler DE, Tyor WR. Neurosarcoidosis. Curr Treat Options Neurol. 2007;9:161-8. doi: 10.1007/BF02938405. 
Sažetak

\title{
NEUOBIČAJEN KLINIČKI TIJEK NEUROSARKOIDOZE S RAZVOJEM HIDROCEFALUSA
}

\author{
D. Jovanović, D. Grujičic, M. Stjepanović, S. Popević, M. Kontić i V. Vučinić Mihailović
}

Oko 5\% do 15\% bolesnika sa sistemskom sarkoidozom razviju neurološke komplikacije. Međutim, stvarna učestalost subkliničke bolesti može biti veća. Simptomi nisu specifični, a mogu sličiti onima drugih neuroloških bolesti. Hidrocefalus se pojavljuje u 6\% bolesnika s neurosarkoidozom. Akutni hidrocefalus je iznimno rijedak, a kada se pojavi obično se teško dijagnosticira, što dovodi do mogućih komplikacija. Prikazujemo bolesnika u kojega se razvio akutni hidrocefalus zbog neurosarkoidoze, zato je morao biti operiran, no ubrzo nakon operacije kranijuma razvija se infekcija koja zahtijeva definitivnu kanalizaciju, ugradnju ventrikularnog šanta. U daljnjem kompliciranom kliničkom tijeku, nakon četiri godine kortikosteroidne terapije (o kortikosteroidima ovisna sarkoidoza), morao je biti hitno operiran zbog značajnih priraslica na ventrikularnom kateteru, ali je nekoliko dana nakon operacije umro u komi zbog progresivnog edema mozga koji nije reagirao na liječenje. Kako hidrocefalus kod neurosarkoidoze ima visok pobol i smrtnost, rano otkrivanje i odgovarajuće liječenje osobito su važni.

Ključne riječi: Sarkoidoza; Neurosarkoidoza; Hidrocefalus; Liječenje 